\title{
Analysis About Some Problems in the Control of Plead Guilty Plea System
}

\author{
Wu Yuehong \\ School of Politics and Law, Guangdong University of Technology \\ Guangzhou510090, China \\ E-mail:913604013@qq.com
}

\begin{abstract}
It is a huge systematic project to promote the trialcentered litigation system reform, aiming at solving the problem of "detection out of control", "restricting failure" and "out of control". The ultimate goal is to promote criminal justice, Criminal justice authority. To the criminal expedition process pilot initial success as an inducement, the Chinese plea guilty penalty system from the pilot system to further expand. This article aims to effectively promote the trial as the center of the litigation system reform, improve the plea guilty plea. Through the scientific definition of pleading guilty on the basis of the concept of broad system control, the appropriate control of plea guilty leniency system and the relationship between the existing criminal proceedings, pleaded guilty plea from the wide system of the standard and pleaded guilty plea, Order to advance the orderly conduct of the current judicial system reform.
\end{abstract}

Keywords-plead guilty; leniency; control; criminal proceedings; proof standard; trial level

\section{INTRODUCTION}

To the criminal expedition process pilot initial success as an inducement, pleaded guilty plea for the broader system of pilot work to further expand. In order to effectively promote the trial as the center of the litigation system reform, improve the plea guilty plea, It is necessary to scientifically define the crime of pleading guilty on the basis of the concept of lenient system control, and to control the relationship between the system of verdict and the existing criminal procedure, the standard of pleading guards and the system of pleading guards, To achieve orderly advancement of the current judicial system reform orderly purpose.

\section{ORGANIZATION OF THE TEXT}

\section{A. Set before the problem}

"Law"... It's a part of a unique way of thinking about the real world.

-- Clifford Giles: "local knowledge: facts and laws in the field of comparison"
In the west, in the process of the disintegration of old identity community relations and the establishment of the new capitalist order, two systems have played a key role, one is the contract in the field of social and private law; the other is order in the realm of state or public law. In our country, the party's 18 Fourth Plenary Session considered and adopted the "CPC Central Committee on Some Major Issues comprehensively promote the rule of law" (hereinafter referred to as the "Decision") that "recognize fine lenient plea perfect system"; January 2016 in The Central Political and Legal Work Conference put forward that, in conjunction with the political and legal units, on the basis of the rational elements of the system such as the defense and arbitration, we should pay close attention to the study of the system of pleading guilty plea for free and wide, and after the authorization of the Standing Committee of the National People's Congress; July 22, 2016,the central leading group comprehensively deepen reforms twentieth meeting examined and adopted the "on the plea recognize fine leniency system reform plan" (hereinafter referred to as "pilot program").September 3,2016,the Twelfth National People's Congress twenty-second meeting voted to adopt a "decision to authorize the Supreme People's Procuratorate carried out in parts of the criminal case pleaded guilty to recognize fine leniency system pilot work" (Hereinafter referred to as "pilot work decision"), to promote the pilot work in 18 cities in an orderly manner, while the pilot time is limited to two years; November 16, 2016, the Supreme People's Procuratorate, Ministry of Public Security, Ministry of State Security, Justice Department Promulgated on "in some areas to carry out criminal cases pleaded guilty plea for leniency system pilot work approach" (hereinafter referred to as "pilot approach")(Figure 1 development context). Accordingly, our plea recognized fine leniency system have come into being [1]. The system on the one hand contains the spirit of contract, on the other hand through the realization of the value of criminal litigation order to reflect the spirit of modern rule of law. However, the relevant laws and their judicial interpretation of China did not clearly stipulate the system of pleading guilty.

This article is the author of the 2016 annual China Postdoctoral Science Fund project "pleaded guilty of the system from the wide control system" (project number: 2016M602437); Guangdong Provincial Department of education quality engineering construction project "industrial law-oriented comprehensive reform of the legal profession" stage Research results.

Author: Guangdong University of Technology School of Politics and Law teachers, doctor of law, postdoctoral; the main research direction: criminal procedure law, judicial system, industrial law, Hong Kong and Macao basic law. 


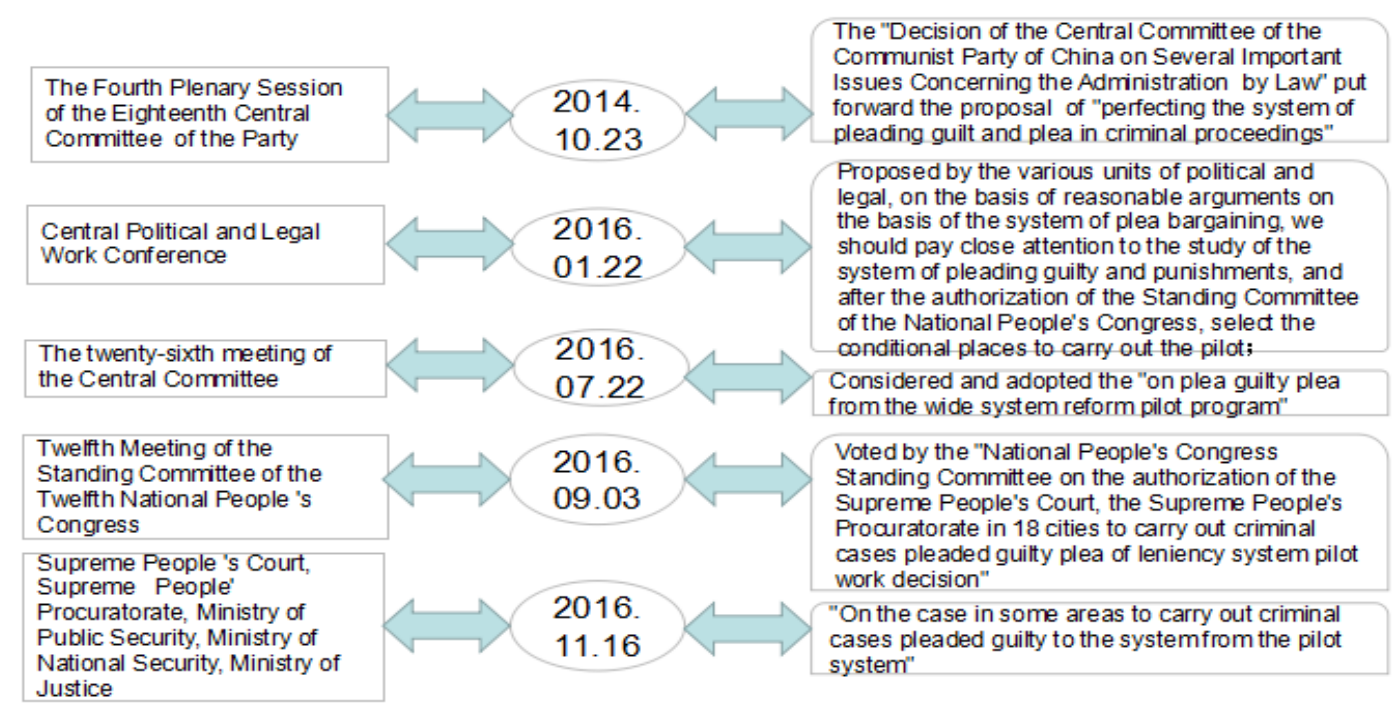

Fig. 1. China's admission of guilt and punishment from the broad system of legal development

The rule of law is a legal ideal of contemporary China's rejuvenation. The spirit contains: 1 it is to arrange the state system, the establishment of law and the concept of the relationship between the ratio of the power of authority; 2 it is a relatively stable, in order to maintain the lofty status law and the law still requires people hold the idea; 3 . It reflects the inherent law of legal operation, the role of domination, evaluation and so on, in the case of power involved in the conduct of the law can lead the public Guangsheng exclusion and ultimately guide people to agree with the authority of the law. Its essence: a stable state of mind of the French people's values and hold selected this relationship in the country and authority interactions. The modern market economy not only requires freedom of competition, but also requires a reasonable system, in which the political emphasis is placed on the establishment of a new type of power structure that guarantees a fair and voluntary distribution - a democratic legal system. The control is to grasp the object without making it any activity or out of range, or making it possible to act according to the wishes of the controller. In order to further improve the current legal system of criminal litigation and democracy in China, it is necessary to clarify the spirit of the rule of law in criminal procedure law. It is necessary to define the concept of the system of guilty plea, to control the relationship between the system and the criminal procedure. Proof standards and trial level control issues [2].

\section{B. The definition of the concept of leniency plea recognized fine control system}

The total goal of "Decision "is to "improve the plea of guilty plea" is not only to achieve the goal of the general goal of the rule of law, While the "Decision" is also the institutionalization and legalization of the criminal policy of temper justice with mercy in our country from the concept, the book to the practice, and the transformation of the hard work, The concept of leniency is the first question in this paper. The concept of the definition of admission of guilt and punishment is the basic premise of the control of the leniency system and the internal logic of the operation of the system. When we define the concept of leniency, we define the concept of lenient system, and then expand to the general meaning of leniency control, and finally to its specific meaning. As a combination of language - - pleaded guilty plea lenient system control, the core for the control, pleaded guilty to the leniency system is its qualifier.

Anglo-American legal system of the defendant does not plead guilty to the case of formal trial procedures, the defendant pleaded guilty cases are applicable to informal trial procedures, such as plea sentence procedures, plea bargaining procedures. Civil law countries for felony cases generally apply the formal trial procedure, the defendant pleaded guilty of misdemeanor cases are more simple procedures. In 2003, China put forward the concept of "confessed leniency". Such as the Supreme People's Court in 2003, the Supreme People's Procuratorate, the Ministry of Justice jointly promulgated the "on the application of ordinary proceedings for the defendant plea a number of cases (Trial)" (hereinafter referred to as "opinion (Trial)").The "opinion (trial)" on the defendant to take the initiative to plead guilty of how the case should be different from the general case of the handling of the initial system. Article 9 provides that: "the people's court on the voluntary plea of the defendant, as appropriate, be punished. "This is the first time in China clearly put forward the concept of "confessed leniency". Subsequently, the practice sector began to explore and use the "plea guilty system. "Before the introduction of the "pilot approach", the academic community on the "confession" concept is that the system is running in a fuzzy state. Pilot approach" issued a clear "confession", "mark" and "lenient" concept, Put forward the "plead guilty" as a criminal suspect, the defendant's recognition of the main facts of the crime, "pleaded guilty" as a criminal suspect, the defendant voluntarily accepted on the basis of plea may be sentenced , "Leniency" both substantive and procedural [3]. In the entity, the lenient expression of sentencing on the concessions; in the program, lenient performance for the proceedings to simplify. But the concept of pleading guilty plea is not clear. When it comes to the concept of pleading guilty 
and leniency, the famous scholar Bentham points out that "the meaning of the word is different depending on the subject of the discussion, and if it is a legal system that has been established, The crime is prohibited by the legislator. If it is for the creation of a code of the best possible theoretical research, according to the principle of utilitarianism, plea guilty plea shall be based on all can be generated or may be guilty. The reason for the punishment and the belief that the act should be punished lenient [4].

However, the plea of guilty plea is not a legal term in China. At present, the authoritative department has not defined the definition of "pleading guilty and leniency system". The academic and practical circles have different definitions and interpretations, has not yet reached a consensus. For example, some scholars believe that the meaning of plea guilty plea should be based on the suspects, from the entity to make leniency, light, reduce, remove the punishment of the treatment, or from the proceedings to make a decision not to prosecute or change, the lifting of coercive measures and other procedural decisions, and even transferred to the relevant authorities for administrative penalties; Some scholars believe that plea guilty leniency system is a system arrangement that refers to the criminal proceedings, the suspects, the defendant admitted to the charges he was charged and willing to accept criminal penalties, and then with the national prosecution force to reach an agreement, and ultimately get a relatively light punishment [5]. In the head of the text, Krishna Gilles mentions that "law" is an integral part of a unique way of enforcing the real world. The criminal procedure system as a subsystem of the legal system, its reform can not be separated from the outside world law system and China's "former rule of law" reality. If we leave the "rule of law before the rule of law" on China's criminal proceedings to plead guilty of lenient system control problems, then it is likely to fall into the pure concept, legal concepts and technical aspects of the analysis, as the grafting of plants does not take into account the soil and climate, as the transplantation of human organs does not take into account the differences between receptors and donors, the effect can be imagined.

Accurate definition the concept of plea guilty leniency is very necessary that start from the dimension of the meaning, the elements, the internal logic and the basic content of the system.1. From the literal point of view, plead guilty plea shall be defined as the perpetrators and defendants who take the initiative to admit the offense, and the defendants who take the initiative to accept the penalty, set up and implement the statutory leniency to highlight And to implement the principle of accepting the crime and punishment, and to achieve the multiple value of criminal justice applied to a system.2.From the constituent elements. The system of guilty plea and guilty shall be composed of three elements: "pleading guilty", "mark" and "leniency".3. From the internal logic, plead guilty plea for leniency, plead guilty, confessed, lenient and deceptive procedures is a separate meaning of the content. The "recognition" in the leniency system refers to the choice of the organ that the criminal suspect and the defendant have voluntarily made on the basis of the true consciousness expressed the correct understanding of the plea confession system. What is pleaded guilty? From the perspective of substantive law, pleaded guilty is a broad concept, which should include "confessions" and "self-surrender" as stipulated in the criminal law, as well as other possible situations.

From the perspective of procedural law, "pleaded guilty" means that there is no objection to the alleged crime; what is the "penalty"? In the current criminal procedure law in our country, although established the summary procedure, simplified ordinary procedure, but the two systems are based on the accused man "confession" and set up, so there is no in commenting on "forfeit" the authority of the specification. In 2014 the supreme people's court, the supreme people's procuratorate, ministry of public security, justice of criminal cases in the areas in the department of speed and cutting of the pilot program measures stipulated in article 1: "The suspects and defendants agree with the sentencing sent by the People's Procuratorate suggested". Where "agree with the sentencing sent by the People's Procuratorate suggested" can be understood as "mark". Based on this, the penalty is in the criminal suspects, the defendant on the basis of pleading guilty of statutory punishment; What is the approved procedure? A criminal suspect or defendant, on the basis of a confession or punishment, voluntarily chooses or agrees to a certain simplification of the proceedings. It should not be included in the "mark", because the two acts of different attributes, recognition of procedural simplification is a legal right, the penalty is a statutory punishment; What is wide? It refers to the prosecutor pleaded guilty, plea, recognition procedures on the basis of the entity, the procedure on the suspects, the defendant lenient treatment. Visiblely, pleaded guilty to forfeit their light system is simplified, forfeit their confession [6], recognition procedure with no content of the four single regressive step by step a unity, is a collection of entity and procedure in an integrated legal system.4. From the basic content point of view, plead guilty of the basic content of the system from the broad, including pleading guilty, confession, recognition of procedural simplification and broad four aspects.

The author believes that the plea of guilty plea is defined in criminal proceedings, from the substantive and procedural encouragement to ensure that the guilty of the suspects, the defendant voluntarily pleaded guilty and leniently dealt with by a series of specific legal system, the judiciary The concept and the legal system of the proceedings [7].

\section{There are two characteristics:}

(1) Admission of guilty plea from the broad system and the criminal substantive law and the procedural law. The pursuit of the value idea of criminal litigation cannot be divorced from the basic principle of punishment, which can not be used to meet the needs of a temporary utility, and damages the criminal policy of justice and stability. "Plead guilty" that contains the defendant's alleged identity of the crime, but also contains a quick trial of the simple procedure of choice; "Leniency" is the substantive sentencing and reduce the defendant's procedural burden on both aspects of leniency.

(2) Plead guilty plea and leniency system is closely linked to simplified processing procedures. Specific to the guilty plea of lenient system control, refers to in the criminal proceedings field, from the substantive and procedural reasonable control, control and effective encouragement to ensure that the guilty of 
the suspects, the defendant voluntarily pleaded guilty and lenient punishment a legal system consisting of a series of specific legal systems, judicial ideas and litigation procedures.

\section{The relationship between the guilty plea guilty of leniency system and the criminal proceedings control}

Criminal litigation is one of the important tools for the state and government to achieve social control and other governance objectives. Different from the authorization of the criminal law, each penalty is set up to set a right for the state organs that have the right to perform the punishment. The criminal procedure law is a restricted law restricting the public power. The object of adjustment is mainly the public authority of the state and its staff. The public authority shall be governed by the criminal procedure law. This is the right organ. Organs of the provisions of the law enforcement agencies in the law enforcement may appear when the constraints of the state. Therefore, if it is not guaranteed by the system, the criminal procedure law can easily lead to execution difficulties. However, there is no uniform definition of the concept of criminal procedure in academic and theoretical circles.

The concept of procedure can be refined from the following dimensions:

(1) In the semantic dimension, the word "program" in Chinese is especially lacking in precise definition. The commencement of the event, the order of the program, the control code of the computer(program), the operation of the experiment, the behavior of litigation are collectively referred to as procedures. The notion of a clear criminal procedure not only provides precise terminology, but also attempts to provide the necessary analytical framework for understanding the procedure.

(2) From the perspective of the law, "procedure" is mainly reflected in a certain order, manner and means to make the decision of the relationship. The general form is: in accordance with a certain standard and conditions to sort out the issue, fair to listen to the views of the parties, so that the parties can understand or recognize the case to make a decision. But the procedure can not be simply reduced to the decision process, because the procedure also contains the premise of the establishment of the decision, there is about the parties after the completion of the behavior of the attitude of the opportunity, and retain the possibility of objective decision-making process. The criminal procedure is practiced in the form of "experimental legislation", which effectively avoids the principle that the legislation of the civil law system is too much and may lead to the accurate application of the law. It is manifested as the problem of poor law enforcement. But the rule of good law requires the joint action of justice and legislation, so that the good wishes of the legislator can fit the basic national conditions and the objective laws of the development of a country, so that the law can have vitality .I believe that the criminal proceedings refers to the provisions of the law in the criminal proceedings in the use of specific methods, steps, Such as filing, investigation, prosecution, trial, implementation and other specific method steps, and refers to the principles that the judiciary should follow in the course of criminal proceedings, the rights and obligations of the parties and other litigants in criminal proceedings.

The jurist Baccarat said: the litigation itself should end in as short a time as it is because the more punishable and timely the punishment of crime is the more just and the benefit .The abolition of dangerous driving and the abolition of the labor education system has brought a large number of petty criminal cases into China's court system, bringing new challenges to the trial work. In order to improve efficiency, improve our current criminal proceedings in China, more area began to try to plead guilty to the leniency system. Such as August 10, 2016, Guangdong Province, Guangzhou City, Nansha District People's Court held a trial of illegal trafficking in ammunition case is a test of the system to apply the water.D.E. Ept said: "When a culture presents an attitude of exploring and asking people how to choose - including moral (or normative), social (or structural), personal (or behavioral) choices - as a noneconomic process The choice of this is the center of the problem ...... from the point of view on the choice of further, the legal system becomes a set for a particular group of choice system. It can be said that the completeness of the procedure can be regarded as a fundamental indicator of the modernization of the rule of law [8]. N. Lumen once discussed the relationship between choice and procedure that: "The socalled procedure, which is the system of mutual behavior prepared for the choice of legal decisions, is freed from the image of the concrete behavior that emerges in the mind. In order to have a more abstract conceptual nature, it is necessary to achieve the inherent nature of the concept. It is this reason that leads to the development of such a unique order of behavior." In other words, there is a gap between abstract norms and concrete cases, which are filled by effective selection procedures. In this article, the relationship between the plea bargain and the existing criminal procedure should be controlled as follows: The plea bargain system is an important part of the current criminal procedure and can now choose to embed the former in the latter coexist in the current criminal The way of litigation is in line with procedural rational ideas and ideas. Because the litigation in any time is the last resort to resolve the dispute, the purpose of the litigation is to meet certain requirements under the conditions of the epistemological requirements of the parties to the disputed rights and interests to judge [9], thus revealing the interests of the dispute is litigation premise.

We know that the law of the paper and the actual operation of the law concept is different, but closely related. If the criminal proceedings as a paper on the law, then plead guilty of leniency system is the actual operation of the law. This is especially true for a country that is not a rule of law or a rule of law. If only from the paper on the law to find the problem and then analyze the problem, solve the problem, obviously not feasible. German scholar Rad Brewer to this limited to the concept and structural analysis of the study called "law philosophy euthanasia". In the context of non-rule of law, China's criminal procedure system in some cases is not in accordance with the provisions of the paper to run, that is, litigation system "alienation." Therefore, in order to analyze China's "real" criminal procedure system, in addition to the need to know the law on the law, but also should understand 
and properly improve the actual operation of criminal law, and properly handle the relationship between the two. There must be a dispute between the parties to the dispute, to determine the criminal suspects, the defendant's guilt may have the impact of the requirements of the rigor of the proceedings and the judiciary based on the sudden increase in the case of the pursuit of efficiency, two There may be a conflict between the need to control the relationship between the two in order to make our current judicial reform on a benign track. Some scholars have said: "litigation trial is not a priority, people will first try to avoid disputes, can not avoid the time to take more consultations and negotiations to resolve the solution between the two sides negotiate, the negotiations will be no help to a third party Only when informal forms of social control are ineffective are litigation used as a last resort." I believe that more and more scholars and policy callers recognize that the use of state-controlled criminal justice machines, which are unrelated to morality, can be used by the state-controlled criminal justice machines to compromise the emotional needs of victims, offenders and the public. To some extent, to resolve the issue of refusal to plead guilty, repentance and apology. It can better serve the current judicial reform if the compromise of the system can be embedded in the current criminal procedure system as an important part of the criminal procedure.

\section{The plea of guilty plea in the liberal system of proof of standard control}

With the advent of the great industrial age, the consequences of the 20th century in the law to be implemented. In today's China, the "industrial spirit" is not a hot word, but this does not mean that China has a sufficient industrial spirit, study the industrialization of the developed countries, and then compare the existence of today's Chinese society seems difficult to solve the problem, It is not difficult to conclude that industrialization is not just material changes, more importantly, the spirit of temperament updates. The spirit of cooperation is the first industrial spirit, the spirit of contract is the cornerstone of industrial civilization. Moderate regulation of plea guilty plea from the wide system of leniency system is the standard of China's industrial spirit of the system embodied. Proof of the standard, refers to the law, to prove the responsibility of the main use of evidence to prove the fact that the degree to be achieved. The basic theory of objective reality that the subjective truth and legal truth that the solution is to prove to what extent the problem. Civil law system of criminal proceedings to prove that the standard is "convinced", AngloAmerican legal system to prove that the standard is "to exclude reasonable doubt". China's criminal proceedings in general proceedings to detect the end of the prosecution and court decision to prove the standard is "the facts are clear, the evidence is true and sufficient", and the 2012 "Criminal Procedure Law" for the first time at the legislative level will "determine the facts have been reasonable Doubt "as one of the conditions of the" facts of the case is clear, the evidence is true and adequate ".In 2014, the Standing Committee of the National People's Congress authorized the Supreme Court, the Supreme Procuratorate in the country's 18 cities for two years of "criminal speed process" pilot work. In 2016, the Standing Committee of the National People's Congress once again authorized the Supreme Court, the Supreme Procuratorate in the same 18 cities for a period of two years, "pleaded guilty plea," the pilot work. China's theoretical and practical circles in the plea of guilty plea in the system has not reached the "facts of the case clearly, the evidence is true, full" standard should be how to deal with? There are two factions view: 1 . According to "doubt from no" treatment; 2. Drawing on the US plea bargaining in the "post-negotiation allegations" to deal with. However, in the pilot work of the criminal expedition process, many practitioners in the practice sector have proposed that the standard of proof of the system should be lower than the standard of proof of ordinary procedure in criminal proceedings. Reason: If the defendant voluntarily pleaded guilty, before the hearing, the sole judge is equivalent to confirm the prosecution charged with the crime facts and charges, the prosecution is equivalent to the adoption of the views of the defendant to the court to deal with the sentencing recommendations, At this point, the defendant basically no objection to the sentencing program, making the court trial in the conviction, sentencing links in name only, and then lead to the criminal procedure law established by the legal proof of the standard without substantive significance. It is also somebody argued that the plea of pleading guilty to the criminal expedition procedure should continue to adhere to the standard of proof that the facts of the case are clear and the evidence is true and sufficient, but the level of the standard of proof can be grasped according to the characteristics of such cases. Some people think that moderate to relax the certification standards. There is no need for exactly the same standard of proof as the case of a simple and minor criminal case where the defendant pleads guilty. It is necessary to substantially reduce the burden of proof of grassroots judges and prosecutors, and to improve the application rate of speed-cutting procedures. In March 2017 by the China postdoctoral science foundation of guangdong university of technology project team is guangdong area criminal speed cutting program pilot effect by questionnaire survey, $72 \%$ of the judges, $69 \%$ of the prosecutors and $88 \%$ of the police were promulgating the attitude of lowering the standard of certification in criminal speedy proceedings. How to control the standard of proof in the lenient system? Academics have not yet reached a consensus. Sheidenko argues that the level of conviction that the standard is to be determined in the plea of the plea of the system (including the summary procedure) may be appropriately lower than the "reasonable excuse" required by the ordinary procedure. Chen Guangzhong, Ma Kang advocated pleading guilty leniency system standards should still adhere to the "facts of the case clear, the evidence is true, full", and only need "basic facts" [refers to the prosecution of the convicted and convicted of the main criminal facts and circumstances. ] Clear and "basic evidence" [refers to evidence that can prove the existence of the basic facts of the case. It is true that the standard is considered to be sufficient. I believe that the plea of guilty plea from the wide system of proof of the standard to deal with the facts of the crime, sentencing facts to distinguish the standard of treatment. The court found that the defendant's facts of the crime of proof of the standard should be strictly enforce the standard of proof of criminal proceedings, that is, the facts are clear, the evidence is true, full, excluding reasonable doubts; prosecutors found that the defendant's criminal real-time proof 
of the standard can be lower than the standard of criminal proceedings, That the facts of the case are clear and the evidence is sufficient [10].

(1) Proof of crime facts: the facts of the case are clear, the evidence is true, full, excluding reasonable doubts. The American Evidence Law and the Criminal Procedure Act gave birth to a trial system, a juror (unlike German and French jurors) often get ridiculous, after screening the fragmented facts. The key to the criminal trial in the United States is to establish a number of obstacles on the way to the judgments. The exclusion and prohibition of evidence constitute a systematic form of protection of the defendant: if the fact that the judge can not determine what has happened, the prosecution wants to win the conviction and "would rather misplaced ten guilty people, not an injustice an innocent" moral principles of the same strain. China's evidence law theory that the prosecution of the prosecution of the crime to bear the burden of proof of the facts, the court for conviction to meet the "facts of the case clear, the evidence is indeed, fully, to exclude reasonable doubt" proof of the standard. The principle of presumption of innocence not only requires the procuratorial organ to bear the burden of proof on the facts of the crime, but also to ensure that the facts are clear, Reasonable proof of the standard, but also on the prosecution is not conducive to the defendant's sentencing circumstances to meet the standard of proof; real truth is to find the truth in the facts of the evidence concept, the court should be loyal to the case The truth of the truth. According to this, based on the principle of presumption of innocence, the requirements of the principle of truth and the need to avoid the miscarriage of justice, the prosecution is concerned about the fact that it is necessary to reach the facts of the case, The evidence is true, full, and the reasonable proof of reasonable proof, Because the above will not be because the defendant pleaded guilty and disappear, the principle of presumption of innocence, the real principle of truth to continue to play a role in preventing injustice is still a difficult task.

(2) Proof of sentencing facts: the facts of the case are clear and the evidence is sufficient. The expansion of state power in modern society leads to alienation of human beings, and the argument for this question has a long history. From the legal dimension, how can we change the state of the people's weakness? There are two kinds of propositions: one is the illegal claim, usually manifested as communityism, emphasizing the interests of compromise type of consensual; Second, the legal system of the idea of democracy, usually expressed in the decision-making process of the parties doctrine, emphasizing the reason for the type of consensual. No matter what kind of assertion, are stressed that consensual, pleaded guilty plea is the system of the above two kinds of claims. It can be seen that in order to attract more defendants to choose to plead guilty and agree to apply the simple trial procedure, the procuratorial organ does not need to meet the statutory maximum certification standard for the proof of sentencing facts. Even for those who are not conducive to the defendant's sentencing circumstances, such as the principal, recidivist, recidivist, abettor, etc., do not need to rule out the reasonable proof of the standard. Reducing the standard of factuality of the sentencing facts will not only destroy the presumption of innocence and the truth of the truth, nor will it result in miscarriage of justice, but will cause the case to be heard quickly, the efficiency of litigation will be improved and the judicial resources will be properly allocated.

In addition, in the judicial practice, our court will "guilty attitude" as the discretion of the plot, especially the "guilty attitude is not good, unreasonable sophistry" as the plot from the weight. But unfortunately, for the plea after the penalty is not necessarily be able to lenient, and "wide" the extent of how such issues, our law is still vague, in the evaluation of the attitude of the guilty, but also reflects a strong subjective color. Justice is a process of compromise between stability and movement. In order to promote justice and effectively promote plea guilty plea, this article argues that plea guilty pleadings must ensure that the case is punishable, punish the crime, avoid unilaterally strict and blindly lenient; the nature of the crime is bad, the criminal means cruel, the society Serious criminals, the confession of confession is not enough to light punishment, but also must be severely punished according to law.

\section{E. Pleaded guilty plea in the leniency system in the trial level control}

The expedition of an important right for a criminal defendant, as early as 1215 , the British Charter stipulates that the defendant has the right to a quick trial. American scholar Franz. Newman said: where there is no restrictions on the discretion, where there is no legal system at all. It is a matter of law to make proper control of the plea of plea guilty plea. The industry is more than any other industry, and the industry does not lack any raw material. The supply of crime seems to be endless. The industry has not only no pollution problems that other industries usually have, but also regarded as a clear understanding of the social system and retain the elements of the industry. The preliminary success of the criminal expedition procedure shows that some prosecutors and judges believe that the trial of the criminal trial can be implemented in the first instance of the trial can be successful, then the plea of guilty plea shall be practicable in the first instance, but this view debatable.

Data show that in 2014 to 2016 during the criminal expedition process pilot period, all the speed of the case of the defendant's appeal rate of only $2.01 \%$, the prosecution rate of only $0.01 \%$. In 2016, the court of all levels of the court examined 1,099,000 criminal cases and sentenced 1234, 000 criminals, respectively, up $7.5 \%$ and $4 \%$ respectively. According to the provisions of the Decision and the Measures of the Supreme People's Court, the Supreme People's Procuratorate, the Ministry of Public Security and the Ministry of Justice on the pilot work on the speedy procedure of criminal cases in the departmental areas, the application of the criminal procedure is required. Facts, laws, procedures, and even penalties are basically no controversy, which seems to mean that both sides of the prosecution and acceptance of the verdict should be able to reach or close to one hundred percent. However, according to the author in the $\mathrm{M}$ province $\mathrm{N}$ area research that, empirical research results show a different scene. Statistics found that the application of criminal expeditions concluded in 1358 cases, the appeal of 13 cases, the appeal rate of $0.96 \%$; no protest cases 
In addition, the survey conducted by China University of Political Science and Law in 2016 on the pilot effect of the criminal expedition process shows that up to $75 \%$ of the judges, $61 \%$ of the prosecutors and $62 \%$ of the police endorsed the first instance of the criminal trial. The author found that greater forfeit their system after the pilot, pleaded guilty at the 2016 implementation of the national more grass-roots court on the defendant to forfeit all made relatively lenient sentencing decision, mostly in sentencing the defendant has no objection, no appeal. Guangzhou, for example, since 2017, the city of Guangzhou 11 grassroots courts concluded the plea guilty plea 2883 cases of 3071 people, accounting for the city's primary court over the same period the first instance of the total number of criminal cases $60.76 \%$. A total of 2582 people were severely punished; in court sentenced 2417, the court pronounced rate of 83.84\%; the defendant appeal only 33, the appeal rate of $1.14 \%$.There are 2168 cases for the speedy procedure, 519 cases for summary proceedings and 196 cases for ordinary proceedings. In addition, the defendant pleaded guilty as an independent and indiscriminate case to consider the case of 1408 cases, the quality of the case was a comprehensive upgrade. In the field of litigation law, the reform of the first instance trial reform has been in the civil procedure law to implement and implement. China's 2012 "Civil Procedure Law" clearly stipulates the relevant standards on the subject of small litigation, that is, the provinces, municipalities and autonomous regions last year, the average wage of $30 \%$ of the following jobs, according to the National Bureau of Statistics published in 2013 urban employment wages to calculate Civil and commercial cases of the subject matter of litigation in the 15442 yuan can be applied below the small litigation procedures, while horizontal comparison of the relevant institutions published around the relevant standards are also in accordance with this proportion and combined with their actual situation to establish a small litigation case standards. Such cases, the grassroots courts in addition to the application of summary procedures, but also the implementation of the first instance trial system, the primary court's first instance verdict once declared that the legal effect. According to this, some scholars believe that, since the civil litigation in the small litigation system in the introduction of the first instance trial system, then the criminal procedure law in the plea of the penalty system can also be introduced in the first trial. There are two reasons: First, the introduction of the first instance trial system can not only simplify the proceedings, reduce the closure of the cycle, but also can improve the efficiency of litigation. In addition, the data show that the prosecution rate of the prosecution rate of the prosecution authorities is almost 0 in the case of the grassroots courts in the case of the application of the criminal expedition procedure which may be sentenced to one year's imprisonment, Second, the beginning of the trial in 2016 to plead guilty of leniency system may be sentenced to three years imprisonment of the following minor penalties for the implementation of the first instance trial system, the court of second instance can save the court of first instance to determine the facts and the law to re-trial, And usually do not appear sentencing abnormalities terrible situation, but will not cause injustice wrong case. Even if the Court of First Instance finds that the facts or the applicable law are somewhat biased, it will not add too much "wrong cost" and "moral cost".

As a result, the legal profession once again set off in the plea of guilty plea in the implementation of the system of first instance trial reform tide. At present, in order to pursue substantive justice, to achieve fairness on the basis of the judicial efficiency, foreign countries have implemented the final trial system. Take Indonesia example: If the parties are dissatisfied with the result of the High Court's decision, they may continue to appeal to the Supreme Court. The parties need to comply with the two procedures when the appeal is made:

(1) To file an application for appeal to the District Court within 14 days of the decision of the High Court;

(2) Within 14 days after the filing of an application for appeal, submit a notice of appeal to the District Court. Upon receipt of the notice of appeal, the District Court shall notify the other party and the other party may submit a reply within 14 days of receipt of the notice. Upon receipt of the full material of both parties, the District Court shall move the filing to the Supreme Court within 30 days. The verdict of the Supreme Court has the final nature of the parties to both sides have a legal effect, see table 2 for details. 


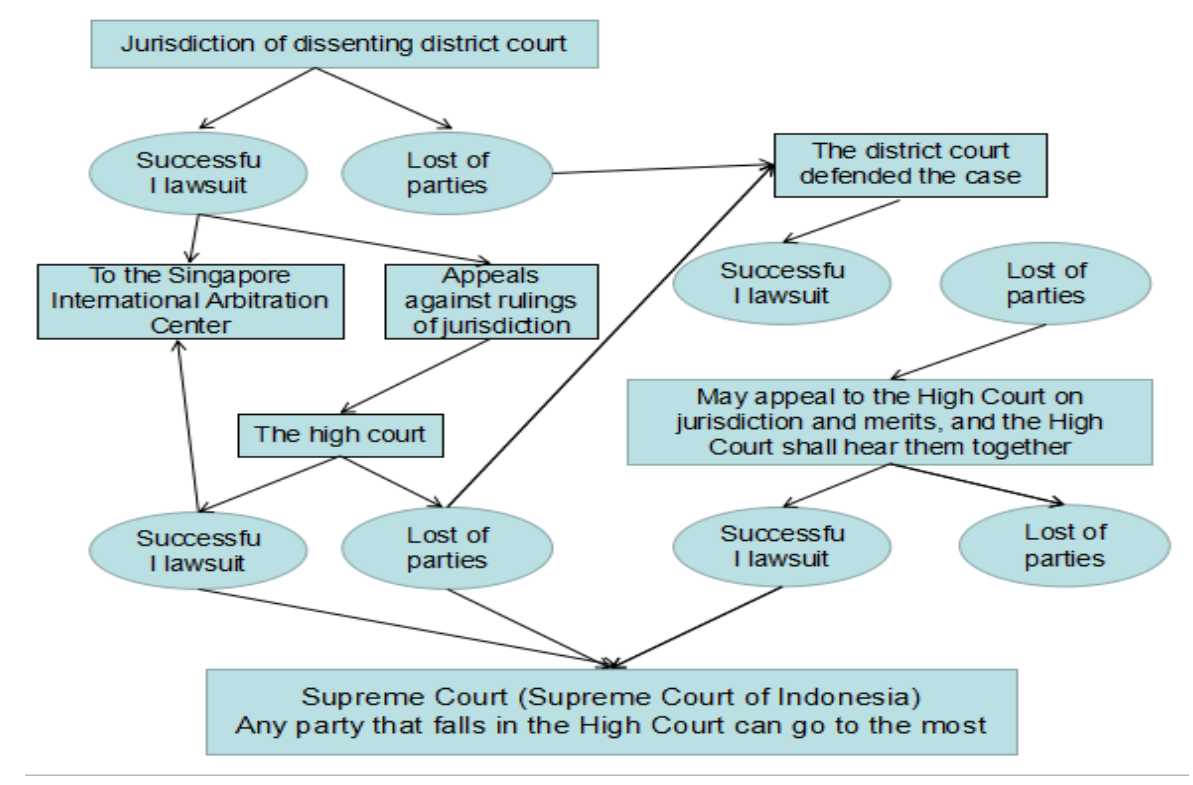

Fig. 2. Indonesian three trial final order flow chart

Throughout the judicial system of our country, the author thinks that the final trial system of the first instance has a certain degree of rationality, but it also breeds a series of negative effects. Therefore, the reform of the first instance trial system is lacking in the criminal procedure mining. There are two reasons: First, from the previous article we can see that in the plea guilty plea policy reform, the appeal rate is only $1.14 \%$, the protest rate is almost 0 .Even if such cases remain in the second instance of the trial system, the number of cases into the second instance procedure is not much; Second, if the guilty plea of leniency from the implementation of the first instance trial system, the parties the right to appeal, the prosecution of the right to protest will not be able to exercise, may lead to miscarriage of justice. First, the defendant can not entrust the defense counsel, in view of the duty lawyers only provide limited legal help, both the defendant or the duty lawyer, can not read the book, it is difficult to understand the prosecutors grasp the evidence, not familiar with the prosecution " ", So that both sides of the information asymmetry of the situation. The defendant's "pleading guilty" voluntary and wise can not be guaranteed. Second, may lead to errors that can not be corrected in the first instance. If the prosecution does not have sufficient and sufficient evidence to support the facts of the charges, the court of first instance does not seriously read, review, trial in the form, may lead to the identification of the facts, or even miscarriage of justice. Third, indulge in the court of first instance. (If the defendant is confined to the pressure of the prosecution, threatening, deception and forced to choose a sentencing program), lost the court of second instance review and correction procedures, the most the results of the referee will be contrary to the original intention of the reform of the system; Fourth, the implementation of the second trial can ensure that the defendant trial procedures and the results of the freedom of choice. As the defendant in the court of first instance in the trial of criminal speed cases always have "go back" right, if the implementation of the first instance trial system, if the defendant retreated, and the right to appeal, can not get relief. Third, the timing is not yet mature. In view of the fact that the small litigation is usually a small civil dispute with a small amount of the subject matter, the economic interests are small and the plea of guilty plea is usually the question of the criminal liability of the defendant, The result of the conviction will be subject to adverse political, social, moral evaluation, be labeled "criminal" label, sentencing results will deprive the defendant of the freedom to limit or confiscate its property. The result of the conviction will render the defendant suffer unfavorable political, social and moral evaluation, labeled "criminal" label, and the sentencing result would deprive the defendant of the freedom to restrict or confiscate his property. Therefore, under the current judicial system, the first instance of the trial system in our country pleaded guilty plea in the wide system also lack the survival of the soil. And the trial system in the third trial also temporarily does not work, because the program cumbersome, the relevant supporting mechanism is not perfect, the series of shock problems have not yet completely resolved, but also deviated from the guilty plea of leniency from the original intention of reform. This paper argues that at present, the system of pleading guilty and punishments is still necessary to maintain the current trial system of the second instance [11]. Therefore, it is necessary to consider the final trial system.

\section{CONCLUSIONS}

As is known to all, the criminal procedure law and as a "civil rights safeguard book" constitution - in Germany, is close to the criminal procedure law is regarded as "seismograph of constitution", in the United States, the criminal procedure has largely been constitution. In general, the litigation trial is not a priority, people will first try to avoid disputes, can not avoid the time to take more consultations and negotiations to resolve the method. When the two sides' efforts are not the result, they will ask for help from the third party. Only when informal forms of social control are lacking in performance, litigation is used as a last resort. In the case of rapid increase in the case, while the judicial resources are 
relatively tense situation, as an important measure to enhance the efficiency of justice, pleading guilty plea to further improve the system and the application is imperative. However, to complete the above tasks, we must first determine the concept of pleading guilty, from the broad system, to properly control the relationship between the system and the criminal procedure, the standard of the system and the trial level, and try to integrate it into the current existing system In the appropriate control of the guilty plea of leniency and the relationship between the above issues, the greatest degree of waste to avoid the judicial resources of the "starting from the stove."

\section{ACKNOWLEDGMENTS}

This work is supported by 2016 annual China Postdoctoral Science Fund project "pleaded guilty of the system from the wide control system" (project number: 2016M602437) and Guangdong Provincial Department of education quality engineering construction project "industrial law-oriented comprehensive reform of the legal profession" fund.

\section{REFERENCES}

[1] Supreme People's Court, Supreme People's Procuratorate Interim Report of the Pilot Project. Standing Committee of the National People's Congress Bulletin, 2015 (6).

[2] The Quantitative Analysis and Relevant Analysis of the Second Trial of the Defendant's Consent Journal of Politics and Law, 2014 (10).

[3] Chen Weidong. Study on the Perfection of the System of Punishing and Punishing Punishments. Chinese Law, 2016 (1).

[4] Gu Yongzhong. Several theories of "perfecting the system of pleading guilty and pleading" Problem [J]. Contemporary Law, 2016, (6).

[5] Li Changsheng. German criminal consultation system [J]. Modern law, 2011, (6).

[6] Peng Dongyu. Guilty plea must be grasped two key points [EB /OL]. (2016-11-04). Http: // www. Npc. Gov Cn / npc /Zgrdzz / 2016-10 / 18 / content_1999347. Htm.

[7] Each criminal speed trial is averaged 5 minutes [EB / OL]. (2016-12 05). Http: // finance Ifeng. Com / a / 20160902 /14852092_0. S.html

[8] Chen Ruihua."Journal of Contemporary Law, 2016 (4): 11 (in Chinese) [J]. Contemporary Law, 2016 (4): 11 (in Chinese with English abstract).

[9] Ding Guofeng. Criminal speed cut the first instance of the final voice is getting higher [N]. Legal Daily, 2015-11-02 (5).

[10] Xiong Qiuhong: "guilty plea, plea bargaining and its attempt in China", contained in China Law Network, May 21, 2016 visit.

[11] Feng Xi-heng: "Sentencing Negotiation in the Procedure of Criminal Punishment - The Practice of Germany and Its Enlightenment to the Establishment of the System of Confession and Punishment in China", "Zhejiang University of Science and Technology"(Social Science Edition) "2016 No. 2. 